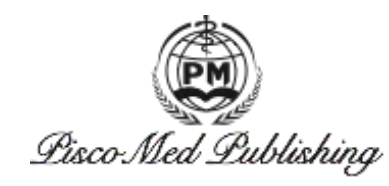

Original Research Article

\title{
Analysis on the Relationship between Accounting and Economic Bene- fits under the New Normal
}

\author{
Jialin Zhao ${ }^{*}$, Hong Zhang ${ }^{2}$, Qiong Li $^{2}$ \\ ${ }^{1}$ Anhui University of Finance and Economics, Bengbu 233030, Anhui, China. E-mail: 1540685081@qq.com \\ ${ }^{2}$ Economic and Technical College of Anhui Agricultural University, Hefei 230000, Anhui, China
}

\begin{abstract}
The new normal economy is the transformation of economic paradigm, economic development mode and economic growth mode. Exploring the relationship between accounting and economic efficiency under the background of the new normal promotes the improvement of the core competitiveness of enterprises, the improvement of core competitiveness of national economy, and the promotion of healthy and sustainable development. The article first briefly introduces the relationship between accounting and economic benefits under the new normal. Since the relationship between the two describes the interaction between accounting and economic benefits, we hope these views can effectively promote the healthy development of social economics.
\end{abstract}

Keywords: New Normal; Accounting; Economic Benefits

As accounting and economic benefits is inseparable under the new normal, the development of accounting is proposed to improve economic efficiency. From another point of view, economic benefit is the purpose of accounting development. In recent years, after China advocated sustainable development, economic efficiency has become an important indicator of sustainable development. Therefore, economic benefits have been widely concerned. However, due to the relationship between accounting and economic benefits, it is of great importance for companies to comprehensively understand the relationship between accounting and economic benefits to make themselves stand out in the new normal competition. Accounting ability directly reflects the economic benefits and development of the company, showing the importance of accounting and its impact on economic benefits and the development of the company. Next, the focus will be on the benefits of accounting and how to improve economic benefits. By using the theoretical system of accounting and economic benefits, the relationship between accounting and economic benefits under the new law is further elaborated.

\section{The relationship between accounting and economic benefits}

\subsection{The relationship between subject and object}

There is a relationship between accounting and economic benefits. Accounting (ACT) is produced through social production practice. It is a means of high-level management, supervision and accounting of economic activities, which is used for economic development and construction. It plays an increasingly important role and belongs to the subject category. Economic benefit is the social labor saved by the exchange of goods and labor, which is the final comprehensive index of all economic activities, based on human subjective consciousness. Transfer is highly objective and belongs

Copyright (C) 2020 Jialin Zhao et al.

doi: 10.18282/ff.v9i4.1446

This is an open-access article distributed under the terms of the Creative Commons Attribution Non-Commercial License

(http://creativecommons.org/licenses/by-nc/4.0/), which permits unrestricted non-commercial use, distribution, and reproduction in any medium, provided the original work is properly cited. 
to the category of objects. The relationship between them is not only the relationship between cognizing and being cognized, but also the relationship between change and being changed. In the process of practice, accounting activities and development are restricted and limited by economic benefits, and may be broken through continuously according to the new law, so as to realize the transformation and upgrading of accounting functions, continuously promote the limit of existing economic benefits through conscious activities, and transform, develop and improve accounting activities and economic benefits.

\subsection{The relationship between purpose and means}

The relationship between accounting and economic benefits can also be reflected as purpose and means, which is dialectical unity. According to the new normal, the transformation and upgrading of accounting functions is a feasible condition to improve the company's and social economic benefits, and is also a force to ensure the realization of economic benefits. People constantly update their financial concepts and create financial value in order to achieve higher economic benefits and consolidate the company's market competitiveness ${ }^{[1]}$, use limited resources to create more social wealth, and meet people's growing material and cultural needs. Economic benefit reflects the proportion between total production and production cost, and reflects people's demand for material and spiritual life. This demand must develop with the development of economic activities and be met by accounting tools. At the same time, new economic benefit targets are put forward to improve economic efficiency, promoting the transformation of economic management methods from "focusing on accounting" to "strengthening management", which restrict and promote each other. Accounting is an important means to improve economic benefits, which is the purpose of accounting development. Therefore, the relationship between purpose and means is also the relationship between accounting and economic benefits.

\subsection{The relationship between theory and practice}

A survey of modern companies shows that there is a link of theory and practice between accounting and economic benefits. Facts have proved that economic interests exist in the form of theoretical relations. Accounting is a practice of economic interests and an important basis for improving economic benefits. In order to realize economic benefits, accounting must be continuously managed and summarized, which is also a practical form.

\section{4 “Consanguinity” dependency}

Many scholars believe that there is a relationship between accounting and financial benefits. The purpose of establishing accounting is to improve the economic benefits, to make the company and its economic management more perfect, and to improve its competitiveness and competitive advantage in the market competition. At the same time, many companies call the relationship between accounting and economic benefits "blood related" dependency, because the improvement of corporate economic benefits is achieved through accounting.

\section{The interaction between accounting and economic benefits under the new normal}

The impact of new normal accounting on economic benefits is more and more obvious, as well as on the company's financial management. Under the new normal, accounting helps to promote the development of companies and economic organizations under the market economy system. Accounting is the basis of the most important work related to economic activities. Accounting is the main method of economic growth. Therefore, in the process of development and competition, it is beneficial for a company's future development to have a comprehensive and profound understanding of the relationship between accounting and economic benefits. Under the new normal, it is necessary to think about how to develop accounting, optimize the allocation of existing accounting resources and maximize the economic efficiency of the company. Secondly, the new normal accounting and the new law can only improve the competitiveness of the company in the economic market, improve its stability and ascendancy, and establish the economic benefit relationship to ensure the trend only through the accurate and comprehensive understanding of the relationship between accounting and economic benefits. 


\subsection{The demand of economic benefits being the basis of accounting}

With the continuous clarification of social division of labor, economic benefit is defined as social labor savings or benefits generated by labor. In order to obtain greater economic benefits, companies or other economic organizations need to implement reasonable resource allocation and labor distribution, and companies or other economic organizations should reduce resource consumption and working time as much as possible. That is, economic activities must be managed effectively ${ }^{[2]}$. The management process of economic activities gives birth to accounting science and promotes the development of accounting management. Generally, the level of economic profit is judged by scientific and reasonable "quantity" accounting, and the accounting methods are roughly divided into accounting and statistical accounting. Among them, accounting information can be obtained more clearly and intuitively through scientific and reasonable accounting methods. Therefore, data plays an important role in economic activities.

\subsection{Improving economic benefits being the goal of accounting activities}

In essence, accounting activity is a micro tool used to calculate economic benefits. It can not only provide information about the basic status of business activities in a period of time, but also be reliable for the company's financial situation and its changes, providing information and helping users make predictions. The comparison and evaluation of financial data is helpful to effectively guide and supervise the financial data of the company's production and operation activities and the profitability of financial resources in the process of achieving economic goals. The direct embodiment of financial data benefits helps to determine the company's ability to use data effectively. At the same time, under the new normal, accounting uses the latest information technology platform as an information management system, breaking the traditional financial "information island", opening the gap between people and finance, which can improve the efficiency of target and physical resource allocation, and maximize the economic benefits of the company by operating and administrative costs. In addition, the high-quality disclosure of economic entity accounting activities reflects and guides the rational allocation of social resources, affects the direction and scale of investors' investment decisions in the capital market, and helps to reduce the market liquidity risk. Through the company control of capital cost, the economic benefit is improved.

\subsection{Economic benefit being the motive force of the development of accounting science}

With the spread of network information, the rapid follow up of "Internet+" and the emergence of "large-scale entrepreneurship and innovation”, the reform and development of accounting need to improve social and economic benefits. First of all, the development of new economy and new business format will change the traditional working concept and promote the transition of accounting activities from "recording value" to "management of creating financial value" and vouchers. It is necessary to carry out accounting activities to overcome the limitations of books, establish "Internet+" thinking and realize accounting function innovation. Secondly, it supports the updating and upgrading of accounting functions relying on the latest information platform, transforming accounting management from "static" to “dynamic”, transforming “post event” accounting into complete process management, and speeding up the conversion ${ }^{[3]}$ The important role of "preliminary forecast" and "management when the event occurs" is to expand the function of accounting supervision, realize the integration and evolution of financial accounting and the latest management, and constantly innovate the production mode and operation mode. From the user level and operation level, financial, multi angle, multi-dimensional evaluation, the company's production/operation status and risk assessment level assessment, as well as the company's internal control ability, the basic model of COSO internal control framework is created and the core competitiveness is enhanced.

\section{Conclusion}

To sum up, although accounting brings economic benefits, it also has a significant impact on improving economic benefits. Economic benefits are the driving force for the continuous development of accounting, and they are closely related. In order to realize the economic benefits of companies and economic organizations, accounting development 
needs to be coordinated with economic development. Therefore, in social and economic activities, doing well in accounting work can improve economic benefits social and promote economic development. Accounting plays an important role in the construction of socialism.

\section{References}

1. He C. Research on the application of management accounting under the new normal (in Chinese). Economist 2016; (9): 155-156.

2. Ge H. Application and development of management accounting under the new economic normal (in Chinese). Shopping mall Modernization 2016; (21): 170-171.

3. Xu D. Analysis of the relationship between accounting and economic benefits under the new normal (in Chinese). Financial Circles (Academic Edition) 2016; (8): 173. 